Годишњак Филозофског факултета у Новом Саду, Кюига ХХХVII (2012)

Annual Review of the Faculty of Philosophy, Novi Sad, Volume XXXVII (2012)

Djura Hardi

UDC 323.15 !398.1(=162.2)(497.11)

Filozofski fakultet Univerziteta u Novom Sadu

Originalan naučni rad

hardyg@ptt.rs

\title{
SEOBE KAO UZROK GUBLJENJA ISTORIJSKE TRADICIJE I PRONALAŽENJA NOVOG IDENTITETA - PARADIGMA MIKROZAJEDNICE RUSINA U SRBIJI
}

U radu se raspravlja o pitanju istorijske tradicije kao odrednice identiteta malih etničkih zajednica na primeru Rusina u Srbiji. Autora posebno interesuje istorijska svest Rusina o njihovoj seobi na tlo današnje Srbije, tj. Vojvodine do koje je došlo pre 260 godina. Specifični problem se istražuje na osnovu rusinskih narodnih hronika i književnosti. Zaključak rada je da se na osnovu relativne svesti o seobi i tome što je njoj prethodilo može objasniti proces gubljenja i pronalaženja nove tradicije.

Ključne reči: istorijska tradicija, identitet, Rusini u Vojvodini i Srbiji, Gavrilo Kosteljnik.

Temu našeg rada, formulisanu u gore navedenom naslovu putem kojeg smo nastojali da što potpunije obuhvatimo polje planiranog istraživanja, možemo rasčlaniti na nekoliko uporišnih pojmova. To su: Rusini u Srbiji; istorijska tradicija/svest kao jedna od determinanti identiteta zajednice, seobe Rusina markirane u kazivanju istorijskih izvora (narodne hronike) i rusinskoj književnosti kao objašnjenje procesa gubljenja i pronalaženja nove istorijske tradicije; primer Gavrila Kosteljnika, utemeljitelja literature kod Rusina u Vojvodini i Srbiji. Za početak, krenućemo s izlaganjem opštih podataka važnih za razumevanje problema.

Rusina u Srbiji danas ima oko 16. 000. Na tlu današnje pokrajine Vojvodine na severu Srbije žive već preko 260 godina. Doselili su se u ove krajeve, tada Južnu Ugarsku, sredinom XVIII veka nakon okončanja austro-turskih ratova (1738), kada su Turci definitivno potisnuti iz srednje Evrope. Nakon oslobođenja velikog prostora Panonije, Habsburška monarhija je novostečene oblasti započela da pacifikuje i 
naseljava s različitim narodima - mahom podanicima Monarhije ili onima koji su se na ovom prostoru od ranije zatekli nošeni vihorom višedecenijskih ratova - Nemcima, Srbima, Mađarima, Bunjevcima, Slovacima... konačno, u tom nizu zajednica koje su baštinile svoj poseban identitet i status našli su se i Rusini.

U Vojvodinu tj. južnu Ugarsku Rusini su stigli iz severoistočnih županija Ugarske i manjim delom iz Galicije - danas su to pogranične oblasti Slovačke, Ukrajine, Mađarske i Poljske. Glavna migracija odigrala se kao kolonizaciona mera između 1745-1765. godine, kada je stiglo oko 400 porodica i zatim još u dve manje migracije tokom XIX veka. Po statusu naseljenici Rusini su bili slobodni ljudi, većinom zemljoradnici, po veri morali su biti grko-katolici, odnosno unijati kako je to bilo određeno u ugovorima o naseljavanju sklopljenim između komorskih vlasti i predstavnika kolonista. Na osnovu takvih ugovora Rusini su naselili dva mesta u Bačkoj: (Ruski) Krstur 1751, i Kucuru 1763. godine. To su bila i matična rusinska naselja iz kojih se dalje u XVIII i XIX veku Rusini raseljavaju u još desetak mesta u Bačkoj i Sremu gde osnivaju svoje crkvene opštine i škole - ustanove koji postaju nacionalni čuvari njihove zajednice. Do 1918. godine oni žive sa ostalim Rusinima ili gledajući na Galiciju Ukrajincima u jednom Carstvu, Habsburškoj monarhiji, odnosno od 1867. godine u Austro-Ugarskoj. Nakon sloma Austro-Ugarske 1918. godine, 21. 000 Rusina ulazi u sastav Kraljevine Srba Hrvata i Slovenaca, tj. u buduću Kraljevinu Jugoslaviju. Kao slovensku manjinu, u oblasti gde su neslovenski narodi bili većina, nova državna vlast na Rusine gleda blagonaklono i ne sputava njihov nacionalni, kulturni i prosvetni život. Dopušta osnivanje državnih škola na rusinskom jeziku, što u poslednjim decenijama Austro-Ugarske nije bio slučaj. Stvaranjem nove države, oni su od tada još više postali izolovoni od svojih sunarodnika u novonastalim državama Čehoslovačkoj, Mađarskoj i Poljskoj. Ali isto tako nisu delili njihovu sudbinu integracije i utapanja u tamošnje državotvorne narode. Nasuprot tome u Kraljevini Jugoslaviji i kasnije u socijalističkoj Jugoslaviji doživljavaju nacionalnokulturni preporod (Gavrilović 1997: 153-215; Рамач Я. 2007). Danas, u Republici Srbiji ova zajednica u tri naselja ima osnovne škole na maternjem jeziku, jednu gimnaziju, Odsek za Rusinski jezik i književnost na Filozofskom fakultetu u Novom Sadu, vlastitu književnost s preko 500 objavljenih naslova, nacionalno - kulturne ustanove, medije. Jezik im je početkom XX veka kodifikovan i pretočen u posebnu slovensku književnost (Tamaš 2002). Slavistika, rusinski danas klasifikuje kao 
posebni slovenski (mikro) jezik i književnost (Дуличенко 1995; Рамач Ю. 2002: $526)$

Rusini u Srbiji se po svojoj nacionalnosti izjašnjavaju kao Rusini. Njihova etnička samoidentifikacija je svesna pogotovo u odnosu na susedne narode u višenacionalnoj pokrajini Vojvodini. Stubovi njihove identifikacije su grkokatolička vera, rusinski jezik kultura i mentalitet. Ali, ako ih pitate šta su oni zapravo po „dubljoj nacionalnosti“ ili istorijskom poreklu, kod njih ne postoji jasan i jedinstven stav. Običan svet najradije se izjašnjava da su oni Rusini /Rusnaci/ doseljeni iz takozvane Gornje zemlje - Gornjice (karpatska tromeđa Slovačke, Ukrajine i Poljske) međutim, potpitanje - da li imaju matičnu državu, naciju i istoriju - nije praćeno jednoglasnim odgovorom. Kolokvijalno rečeno Ukrajinci su im danas već strani po jeziku. Slovaci iz istočne Slovačke govore (skoro) istim jezikom kao i oni, ali Rusini u Srbiji imaju jasnu nacionalnu svest da nisu Slovaci. Takođe, više manje znaju da su Mađari i Slovaci grkokatoličke veroispovesti zapravo njihovi nekadašnji sunarodnici, makar ovi to negirali kao i svi čisti pripadnici državotvornih nacija (bez obzira šta ova kovanica značila). Stoga im se čini da pravi Rusini danas žive jedino u Srbiji. Kod rusinske inteligencije u Srbiji stvar je naizgled manje složena. Podeljeni su na dve opcije. Jednoj pripadaju oni koji drže da su Rusini Ukrajinci. Drugoj oni koja imaju antiukrajinski stav, tj. koji misle da su Rusini poseban narod. Među poslednjima ima više grupa, okrenutih prema rusofilstvu i pravoslavlju ili opciji da su Rusini takozvani Istočnjaci - Vihodnjare, tj. Slovaci iz istočne Slovačke, a u prošlosti barem pre 1918. godine kod bačkih Rusina postojala je opcija da su Rusini deo mađarske nacije. Sadržaj tema na kojima se zasniva sukobljenost po pitanju istorijske i nacionalne opredeljenosti za mikrozajednicu od oko 16000 pripadnika ipak nije sui generis, već je samo odjek onih nacionalnih procesa i sukoba koji su se tokom XIX i XX veka odvijali među Rusinima u severoistočnim oblastima Austro-Ugarske, a zatim i u nacionalnim državama koje su na njenim temeljima iznikle (Magocsi 1978; Скороход 1995: 281-305).

$\mathrm{U}$ ovom nesuglasju, posebno nas međutim interesuje fenomen istorijske svesti kod ove zajednice u Srbiji. Generisana putem autentične ili iskonstruisane istorijske tradicije, istorijska svest jeste oblik društvenog pamćenja, relativno sistematična predstava o vlastitoj prošlosti i tradiciji iskazanoj kroz vremenski kontinuitet. Kao takva ona je deo identiteta zajednice i Rusini u Vojvodini u tom 
pogledu nisu izuzetak. Zbog sprege sa društvenim potrebama istorijska svest je funkcionalna kategorija podložna razvoju i kreiranju od strane elite. Ona je naizgled razapeta između tradicije i stvarne istorije, između istoriografije i književnosti na primer - koje mogu biti bliske, ali ih razdvaja činjenica da istoriografija u idealnom smislu traga za onim što se doista desilo i stoga njenu inspiraciju ograničavaju istorijksi izvori (Hobsbawm, 1992).

Rusini se u Južnu Ugarsku (sredina XVIII v.) doseljavaju u vreme kad etnička, jezička, kulturna, verska i konačno državna pripadnost zajednica tek treba da se pretopi u stvaranje modernih evropskih nacija. Uz sva ograničenja malobrojne zajednice koja je bila (poput mnogo većih zajednica tog tipa) u nedostatku etablirane elite pre objekt nego li kreator istorije, Rusini su sa sobom prirodno doneli izvesnu istorijsku svest. Njihova tanka elita su bili grkokatolički sveštenici i grupa pismenih ljudi.... upravo njima treba pripisati postojanje narodnih hronika kod Rusina u Južnoj Ugarskoj koje predstavljaju najstariji zapisani sloj istorijske tradicije.

Narodne hronike, duže ili kraće po obimu, pisane po svemu sudeći već tokom XVIII, XIX pa i prvih decenija XX veka (kao i druge rukopisne knjige duhovnog karaktera) kod Rusina u Vojvodini imaju tradiciju. Postoje dva letopisna protografa - jedan koji je nastao u Krsturu, drugi u Kucuri - dva najstarija rusinska naselja u Vojvodini. (Рамач Я. 2007: 12-13). Do danas je registrovano više od 12 rukopisnih tekstova hronika, od toga je publikovano integralno ili u izvodu sedam rukopisa, prvi 1903. godine od strane ukrajinskog etnografa Volodimira Hnatjuka u Lavovu (Гнатюк 1903: 5-9). Upravo je hronološki koncept ovih hronika fenomen vredan pažnje i polazna tačka našeg istraživanja.

Naime, sve hronike počinju sa godinom i kratkim vestima o seobi i naseljavanju (Rusina) u Krstur -,, 1746. кед селїц почали; 1747, кед Керестур населєли... “ (Гнатюк 1903: 5), a neke hronike, upravo imaju naslov „Спомин од зачатия Керестура“ ili što je za nas još indikativnije u naslovu se pored Krstura navodi i sintagma pomen od stvaranja sveta „Спомин вични керестурски або Спомин од створеня швета.” (Рамач Я. 1988: 527-530).

Prvi letopisci i njihovi kasniji nastavljači izgleda nisu imali „potrebu“ da se osvrnu ni jednim pomenom na ono šta je bilo pre seobe, odakle, pod kojim uslovima i zbog čega su njihovi sunarodnici stigli u Krstur i potom u Kucuru. Time su prećutno stvorili koncept o seobi kao početku jedne nove istorije, o seobi od 
koje (ad quem) počinje istorija jedne zajednice, a pred kojom (ante quem) se nalazi tabula rasa ili simbolično, u duhu staroslovenskog letopisanija kako je zabeleženo u jednom rukopisu - stvaranje, početak sveta (što opet svedoči da je pisac hronike imao izvesnu predstavu o letopisnoj tradiciji). Istorijska svest o seobi i osnivanju jednog mesta kao početku i krajnjoj granici istorjskog pamćenja zapanjujuće se ukorenila kod Rusina u Vojvodini i razvila kao njihova posebna tradicija. O tome svedoče etnografski zapisi Volodimira Hnatjuka iz 1897. godine kada je posetio Krstur i Kucuru. (В. Гнатюк, (1897/1988: 79-126), kao i istoriografski radovi Gavrila Kosteljnika, nastali prvih decenija XX veka, koji je usvojivši ovu tradiciju o Rusinima ili „Ukrajincima iz Bačke“ kako ih naziva u jednom svom ukrajinskom članku, govorio kao o specijalnom narodu nastalom iz dva naselja Krstura i Kucure. Oni su kroz 150 godina stekli poseban mentalitet, jezik i običaje. Tome je po Kosteljniku doprinela njihova udaljenost od ostalih sunarodnika. Vremenom u novom okruženju i na novom tlu oni su počeli da se izdvajaju od Rusina iz takozvane Gornje zemlje i Galicije. Međutim, Kosteljnik se indikativno ni jednom rečju nije pozabavio onim šta je prethodilo seobi. (Костельник (1915/1998: 3-12; Костельник 1920: 134-137)

Kao objašnjenje stvaranja istorijske tradicije zajednice koja na mitskom činu seobe zasniva fundamente svog početka i stavlja granicu kolektivnog pamćenja mogu se dati nekoliko istoriografski prihvatljivih objašnjenja. Prvo, s obzirom na kontinuitet vesti koje donose, protografi nisu pisani s velike hronološke distance od seobe da bi to bio uzrok zaborava onog što je prethodilo. Odgovor verovatno leži u zavičajnoj heterogenosti i egzistencijalnim prilikama koje su bile prisutne u oblastima severoistočne Ugarske odakle su kolonisti došli. Reč je bila o ekonomski zaostalim krajevima Monarhije, gde su Rusini kao karpatski gorštaci doseljeni mahom iz Galicije na vlaškom pravu stajali na margini društva. Početkom XVIII veka ovde se odigralo najkrvavije poprište Rakocijevog ustanka kada je mađarska plemićka klasa po ko zna koji put pokušala da se oslobodi od vlasti Habsburgovaca i stvori samostalnu Ugarsku. Rusini su, kao i svaka manjina bili uključeni u sukob državotvornih naroda, na strani Rakocija većinom, ali kada je Rakoci 1711. poražen njegovi podanici će još dugo osećati težinu habsburške odmazde. Ovom ratu prethodili su dugi periodi verskih sukoba između plemstva - prohabsburških katolika i mađarskih kalvinista, u kojima su njihovi podanici, među kojima i Rusini - prvo kao pravoslavni, a nakon 1596, i 1646, prevedeni na uniju - bili od obe strane na udaru. 
U takvim uslovima, kada se pročula vest da nakon proterivanja Turaka na jugu Ugarske ima dovoljno puste i slobodne zemlje, najodvažniji ali ipak malobrojni među Rusinima su odlučili da krenu na jug i okušaju sreću. Imali su pregršt motiva da zaborave na siromaštvo i obespravljenost u starom kraju. Na jugu je bilo teško, ali su prvobitno stekli relativno pristojne posede i započeli novi život. Ekonomski su napredovali ugledavši se na novopridošle susede, posebno Nemce. Bili su neposredni podanici državne Komore, dakle, slobodni ljudi na teritoriji gde nije bilo feudalne gospode. Jednostavno, čini nam se da su imali manjak potrebe ili bolje reći dobar motiv da se svesno odreknu prethodnog istorijskog sećanja. „Odbacivanje prošlosti“ otvorilo je mogućnost za stvaranje nove optimističke tradicije. To kidanje sa korenima najbolje se videlo u činjenici da kada je u Krstur (koji je iza sebe imao 100 godišnju tradiciju) sredinom XIX veka stigla nova grupa doseljenika iz starog kraja - iz oblasti oko Bardejova u današnjoj Slovačkoj, a kasnije i iz Galicije - starosedeoci nisu s njima osećali nikakvu bliskost i solidarnost već su ih proterali iz „svog“ naselja. Doduše, u ovom postupku može se prepoznati ne toliko nacionalno kulturološka koliko socijalno-ekonomska i u međuvremenu stvorena jezička distanca između dve grupe istog etničkog i verskog porekla. (Костельник (1915/1998: 7)

Rusini u južnoj Ugarskoj, pogotovo njihova elita sastavljena od sveštenstva i učitelja konfesionalnih škola ipak tokom XVIII i XIX veka nisu prekidali vezu sa starim krajem. Knjige, časopisi, učitelji i iškolovani bogoslovi stizali su iz Lavova, Mukačeva, Užgoroda. Ali podkraj XIX veka i među Rusinima u južnoj Ugarskoj započeo je intenzivni proces integracije u mađarsku naciju, sprovođen preko uvođenja državnih škola na mađarskom jeziku koje su uprkos dva izuzetka (Kucura, Novi Sad) zamenile stare (rusinske) konfesionalne škole. Integracija je imala svoje pristalice među rusinskom elitom, istina i protivnike. Loše po protivnike je bilo to što oni nisu imali jasan uzor zahvaljujući kojem bi se „suprotstavili““ superiornom i perspektivnom državotvornom jeziku, kulturi i tradiciji, već su bili podeljeni na rusofilsku, ukrajinsku i ugro-rusinsku opciju koje su bile recepcija političkonacionalnih podela kod sabraće iz drugih delova Ugarske i Galicije (Magocsi 1978).

I onda, nakon 150 godina proteklih od seobe Rusina u Južnu Ugarsku, odigrao se jedan individualni povratak u istorijsku postojbinu koji je imao presudan značaj za celu zajednicu. Tada zagrebački gimnazijalac Gavrilo Kosteljnik (1886-1948) je 1904. godine uz pomoć svog mentora Volodimira Hnatjuka i ruskog naučnika A. 
Šahmatova u Žovkvi u Galiciji u Poljskoj publikovao prvu knjigu umetničke poezije na rusinskom narodnom jeziku pod naslovom Идилски венєц 3 мойого валалу. Godine 1923. u Lavovu gde je proveo najveći deo svog života, Kosteljnik je sastavio prvu gramatiku jezika Rusina u Vojvodini - Граматику бачванско-рускеј бешеди. S ova dva dela Kosteljnik je postavio temelj rusinske književnosti i izvršio kodifikaciju jezika Rusina u Bačkoj i Sremu (Vojvodini). Kosteljnik po svom društvenom delovanju i političkoj ulozi među ukrajinskom elitom u Galiciji prevazilazi značaj Rusina u Srbiji, ali istinski je ostao samo njihov velikan. (Тамаш 1986).

Skeptičnih je bilo i 1904, i 1923. godine, onih koji su pisali na neživom rusinskom metajeziku (jazičiju) u Budimpeštanskom listu Nedilja, ili koji su tvrdili da Rusini za svoj književni uzor treba da uzmu veliki ruski jezik. U međuvremenu, zbio se slom Austro-Ugarske monarhije, a Rusini u Vojvodini su se našli u Kraljevini SHS. Kosteljnikovo seme je bačeno na plodno tle. Njegova kodifikacija je zaživela u osnovnim školama i postala obrazac razvoja mlade književnosti. Kosteljnik je između dva svetska rata postao duhovni vođa Rusina koji su okupljeni oko grkokatoličke crkve bili nosioci kulturno-nacionalnog preporoda zajednice. Kodifikaciju jezika i utemeljenje književnosti Kosteljnik je sproveo na narodnom jeziku ali je ujedno bio predvodnik generacije itelektualaca koja je Rusine smatrala delom mlade ukrajinske nacije u povoju.

Iz Lavova Kosteljnik je svojim zemljacima u Bačkoj pisao najlepše pesme, pripovetke i drame te postao književni uzor i onim Rusinima koji su naposletku prihvatili njegovu kodifikaciju i pravopis, mada su kao pristalice rusofilstva i pravoslavlja ostali ljuti protivnici ukrajinske nacionalne opcije. Kosteljnikov književni rusinski opus bio je romantičarski i nostalgično okrenut prema zavičaju. U godinama velikih životnih iskušenja koje mu donose crkvene i političke borbe u Poljskoj i Lavovu tridesetih godina XX veka, zatim strahote Drugog svetskog rata i Staljinov teror koji neće preživeti, Kosteljniku je kao beg iz stvarnosti preostao duhovni povratak u mesto odakle je ponikao.

$\mathrm{U}$ međuvremenu razvijala se $\mathrm{i}$ istoriografija kod Rusina $\mathrm{u}$ Jugoslaviji. Njen primarni predmet istraživanja je međutim funkcionalno ostala samo prošlost Rusina od njihovog doseljenja u Bačku i Srem. Ovako omeđena i modelirana kao metodološki koncept istoriografija kod Rusina tokom socijalističke Jugoslavije nije imala društvenog prostora da kod relativno šire publike razvija dublju istorijsku 
tradiciju i nacionalnu svest, sem one utabane s povešću „od osnivanja Krstura“( Харди 2007: 257-267). Teme koje bi prevazilazile ovu prostornu i hronološku granicu predstavljale su opasno i nezahvalno političko pitanje u intelektualnom miljeu zajednice. On je, uslovno rečeno, bio i ostao podeljen na dve nacionalne opcije (ukrajinsku i antiukrajinsku) koje su svoju vitalnost valjda najbolje manifestovale zauzimanjem rukovodećih položaja komunističke nomenklature rezervisane za „rusinsku narodnost“. Pogotovo se to nije moglo učiniti, sve do promena 2000. godine, u okviru školskog sistema. Stoga je preostala književnost, da kao poslednja nada funkcionalno domisli i ukoreni istorijsku tradiciju zajednice. Po uzoru na Kosteljnika, tematika dela njegovih najplodnijih književnih nastavljača Mihajla Kovača i Đure Papharhaja i dalje je ostala u vidokrugu egzistencije rusinskog rustikalnog univerzuma čije je temelje postavio sam Kosteljnik. Doduše ovo je samo jedan kontekst njihovog književnog stvaralaštva koji ujedno počiva i na ukrajinskim, južnoslovenskim i svetskim literaturnim uzorima. (Tamaš 2002: 487-501). U svojoj knjizi eseja Dijaspora (Дияспора) Kovač budući da je Kostelnjikov sledbenik i u nacionalnom pitanju, upustio se u traganje za dubljim istorijksim korenima, iskazujući lakonsku misao koja duboko zadire u pitanje istorijske svesti - da Rusini nisu narod koji je iznikao iz ničega (Ковач 1992). Nasuprot Kovaču, Papharhaji u svojim poemama zatvara panegirički krug opevavanja Krstura i njegove lokalne toponomastike i folklora kao središta vlastitog univerzuma. Istorijkse teme poput tabua o neuspelom pokušaju povratka na pravoslavlje Rusina u prvim godinama nakon seobe, bivaju glavni motiv njegove dramske trilogije Ikone na Коži (Образи на скори) na čelu sa dramom Agafija, starog popa kći (Агафия, старого попа дзивка) (Папгаргаї 1988).

Praznina u hronologiji rusinskih letopisa između postanka sveta, seobe i osnivanja Krstura ostala je u međuvremenu provokativno nepopunjena. Moderni letopisci su se ipak odazvali. Letopis $i$ istorija Ruskog Krstura 1745-1991, autora Julijana Tamaša publikovan 1992. godine, predstavlja monografiju posvećenu ovom naselju sa ambicijom da bude i istorija cele zajednice. Zaključna rezimea, koja stoje na kraju svake celine čije izlaganje teče u vidu imitacije letopisne forme po hronološki progresivnom metodu izlaganja - predstavljaju idejnu poentu dela. U njima, Tamaš kao rečiti filozof istorije traga za dubljim korenima i skrivenim porukama bivstvovanja ove male zajednice na jugu Panonije (Тамаш 1992). 
Konačno, na pragu XXI veka rusinska književnost u Srbiji dobila je dva dela kojima su inspiracija ruski letopisi - od onog Galičko-volinskog do rusinskih letopisa u Bačkoj. Naime, Mihal Ramač u zbirci poezije Čukundedov osmeh (Чукундїдов ошмих) opevava seobu Rusina u Bačku (Рамач M. 2003). Nakon ovog dela od istog autora 2008. godine usledila je poetska trilogija naslovljena Povest o Danilu, Fedoru i Gavrilu (Povest o Danilu, Fedoru i Gavrilu). Sve ono što letopisci nisu zapisali na dragocenim listovima pergamenta i hartije, u visprenom dijalogu s muzom Klio, Ramač u svojim zbirkama pripisuje rečima i delima svojih heroja razapetim između univerzalnog dobra i zla. Njegova trilogija je u istorijskom kontekstu posvećena Danilu Romanoviču, knezu i kralju Galicije iz XIII veka, jednom krsturskom narodnom tribunu iz XIX veka, i nazaobilaznom Gavrilu Kosteljniku. U idejnom smislu Ramač stoji na liniji Karlajlove teze da istoriju čine heroji i tako uvodi Rusine u svet za njih nepoznate epske tradicije. Nakon 260 godina Ramačevo delo po prvi put, prekoračivši granicu do nedavno „lapidarnog istorijskog sećanja i tradicije“ nastoji da popuni prostor istorijskog zaborava. Ostaje da vidimo uticaj njegovog dela na novu istorijsku tradiciju, kod onih kojima je ono namenjeno. (Рамач M. 2008).

\section{IZVORI I LITERATURA:}

Дуличенко, Александер Д. (1995), Jugoslavo-Ruthenika.Нови Сад: Руске слово.

Gavrilović, Slavko (1977). Rusini u Bačkoj i Sremu od sredine XVIII do sredine XIX veka. Godišnjak Društva istoričara Vojvodine, 1977: 153-215.

Гнатюк, Володимир (1897/1988) Руски населєня у Бачки (Южней Угорскей). Етнографични материяли з Угорскей Руси, т. V. Нови Сад: Руске Слово: 79-126.

Гнатюк, Володимир (1903). Керестурська хроніка, Записки наукового товариства імені Т. Шевченка, т. LIII, 1903: 5-9.

Харди, Ђура, Развој историографије код Русина у Војводини до 1941. године, Истраживања, 18/ 2007: 257-267.

Hobsbom, Erik - Rejndžer, Terens (2011.) Izmišljanje tradicije. Beograd: Biblioteka XX vek. 
Ковач, Михайло (1992). Дияспора, драгопис и историйни есей. Нови Сад: Руске Слово.

Костельникї Гавриїл (1915/1998). Liber тетоrabilium Грекокатолӥикей парохиї бачкерестурскей, пририхтал за публикованє Янко Рамач, Нови Сад: Союз Руснацох и Українцох Югославиї.

Костельник, Габор (1920). Бачванські Украӥнці, Календар Просьвіти, 1920: 134-137.

Magocsi, Paul Robert (1978). The Shaping of a National Identity: Subcarpathians Rus'1848-1948, Cembridge Mass. 1978.

Папгаргаї, Дюра (1988). Образи на скори, драмска трилогия, додаток, Шветлосц, XXVI, 1988.

Рамач, Михал (2003). Чукундїдов ошмих, Нови Сад: Руске Слово.

Рамач, Михал (2008). Повист о Данилови и Феркови и Габрови, Нови Сад: Руске Слово.

Рамач, Янко (1988). Спомин вични керестурски або Спомин од створеня швета, Шветлосц, 5/1988: 527- 550.

Рамач, Янко (2007) Руснаци у южней Угорскей, (1745-1918). Нови Сад: BAHY.

Рамач, Юлиян (2002). Граматка руского язика. Београд: Завод за уџбенике и наставна средства Београд.

Скороход, Јуриј С. (1996), Русинско питање у међународним односима. Русини Руснаци 1745-1995, Београд - Нови Сад: Завод за уџбенике и наставна средства Београд: 281-305.

Тамаш, Юлиян (1986). Гавриїл Костельник медзи доктрину и природу, Нови Сад: Руске слово.

Тамаш, Юлиян (1992). Руски Керстур, лїтопоис и традищия (17451991). Руски Керестур: МЗ Руски Керестур.

Tamaš, Julijan (2002) Istorija rusinske književnosti. Novi Sad: Prometej - Ruske Slovo (Na rusinskom jeziku: Тамаш, Юлиян (1997), История рускей литератури. Београд: Завод за уџбенике и наставна средства Београд. 
Đura Hardi

\section{MIGRATIONS AS A CAUSE OF LOSS OF THE HISTORICAL TRADITIONS AND FINDING A NEW IDENTITY - RUTHENIANS MICROCOMMUNITY IN SERBIA}

This paper discusses the question of historical consciousness as a determinant of identity communities in the example of Ruthenians in Serbia. The athor show special interest to the Ruthenians awareness of their migration to Serbia 260 years ago. The specific problem is investigated in based on the narration of historical sources (Ruthenian People's Chronicle), and literature. The conclusion of this work is that we could explain the process of the loss and the finding a new tradition based on the relative awareness of migration and the fact that it preceded

Key words: historical tradition, identity, Ruthenians in Vojvodina and Serbia, Gavrilo Kosteljnik. 